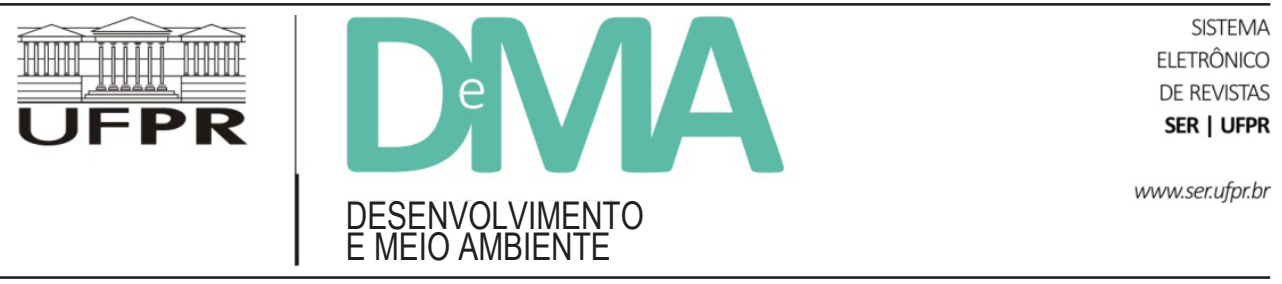

\title{
As esferas de responsabilidade pelo dano ambiental: aplicação ao caso Samarco
}

\section{Spheres of Responsibility for Environmental Damage: Application to Case Samarco}

\author{
Beatriz Duarte Correa de BRITO ${ }^{1 *}$, Josué MASTRODI NETO ${ }^{1}$ \\ ${ }^{1}$ Pontifícia Universidade Católica de Campinas (PUC-Campinas), Campinas, SP, Brasil. \\ *E-mail de contato: beatriz.brito@mail.com
}

Artigo recebido em 15 de junho de 2016, versão final aceita em 1 de novembro de 2016.

RESUMO: Neste breve artigo estudaremos as esferas de responsabilidade do poluidor que causa dano ambiental, em especial as possíveis responsabilidades da mineradora Samarco pelos danos ambientais resultantes do rompimento da barragem de Fundão e do transbordamento da barragem de Santarém. Para tanto, analisaremos a jurisprudência dos tribunais superiores. O presente estudo busca explicar a possibilidade de o poluidor responder perante esferas distintas pelo mesmo fato, sem isso configurar bis in idem, bem como esclarecer a viabilidade de responsabilidade penal da pessoa jurídica diante da impossibilidade da aplicação de pena privativa de liberdade.

Palavras-chave: dano ambiental; esferas de responsabilidade; responsabilidade penal da pessoa jurídica; responsabilidade objetiva e subjetiva; Samarco.

ABSTRACT: In this brief article we will study the polluter spheres of responsibility that causes environmental damage, in particular the possible responsibilities of the mining company Samarco for environmental damage resulting from the disruption of the Fundão dam and overflow of Santarém dam. We aim to analyze the Superior Courts jurisprudence. The present study seeks to explain the possibility of the polluter responding to different spheres by the same fact, without setting bis in idem, as well as clarifying the feasibility of criminal liability of the legal person in view of the impossibility of applying custodial sentence.

Keywords: environmental damage; spheres of responsibility; criminal responsibility of legal entity; objective and subjective responsibility; Samarco. 


\section{Introdução}

Em novembro de 2015, dois eventos marcaram a vida dos moradores de Mariana, uma cidade histórica de Minas Gerais: a barragem de Fundão se rompeu e a barragem de Santarém (ambas pertencentes à mineradora Samarco) transbordou, despejando milhões de metros cúbicos de rejeitos minerais nas águas do rio Doce, uma quantidade de lama tóxica que pode ter determinado a morte de todos os biomas do rio, das barragens até sua foz, no oceano Atlântico. Essa tragédia, de proporções ainda desconhecidas, já é considerada pelos especialistas como o maior desastre ${ }^{1}$ ambiental do Brasil.

Segundo o Laudo Técnico Preliminar do Instituto Brasileiro do Meio Ambiente e dos Recursos Naturais Renováveis (IBAMA), já foram constatados os seguintes prejuízos:

Mortes de trabalhadores da empresa e moradores das comunidades afetadas, sendo que algumas ainda restam desaparecidas; desalojamento de populações; devastação de localidades e a consequente desagregação dos vínculos sociais das comunidades; destruição de estruturas públicas e privadas (edificações, pontes, ruas etc.); destruição de áreas agrícolas e pastos, com perdas de receitas econômicas; interrupção da geração de energia elétrica pelas hidrelétricas atingidas (Candonga, Aimorés e Mascarenhas); destruição de áreas de preservação permanente e vegetação nativa de Mata Atlântica; mortandade de biodiversidade aquática e fauna terrestre; assoreamento de cursos d'água; interrupção do abastecimento de água; interrupção da pesca por tempo indeterminado; interrupção do turismo; perda e fragmentação de habitats; restrição ou enfraquecimento dos serviços ambientais dos ecossistemas; alteração dos padrões de qualidade da água doce, salobra e salgada; sensação de perigo e desamparo na população (Ibama, 2016, p. 4).

No dia 2 de março de 2016, a mineradora Samarco e suas controladoras, Vale e BHP Billiton, assinaram, em Brasília, um Termo de Ajustamento de Conduta (TAC) junto aos governos federal e dos estados de Minas Gerais e Espírito Santo, comprometendo-se a garantir "a recuperação de 42 mil hectares de áreas de preservação degradadas e 5 mil nascentes na bacia do rio Doce" (Ibama, 2016, p. 1). A assinatura desse TAC, no entanto, não eximiu a mineradora e alguns de seus funcionários de toda responsabilidade civil pelos danos ambientais causados, tampouco de quaisquer responsabilidades criminal e administrativa decorrentes do mesmo evento danoso.

O ordenamento jurídico brasileiro, em razão do Pacto Internacional dos Direitos Civis e Políticos da Organização das Nações Unidas (ONU) e da Convenção Interamericana de Direitos Humanos $(\mathrm{CIDH})$ - tratados internacionais dos quais o Brasil é signatário -, adotava o Princípio do non bis in idem, segundo o qual é proibido "que um Estado imponha a um indivíduo uma dupla sanção ou um duplo processo (ne bis) em razão da prática de um mesmo crime (idem)" (Maia, 2005, p. 27). Segundo esse princípio, portanto, a assinatura do termo de compromisso pela mineradora Samarco, assumindo a reparação civil do dano, impediria o prosseguimento de eventuais processos penais e administrativos.

Todavia, a Constituição Federal de 1988 inovou ao introduzir no Direito brasileiro a tríplice

\footnotetext{
${ }^{1}$ Segundo o Glossário de Defesa Civil, Estudos de Riscos e Medicina de Desastres do Ministério do Planejamento (MPOG, p. 57), desastre é o "resultado de eventos adversos, naturais ou provocados pelo homem, sobre um ecossistema (vulnerável), causando danos humanos, materiais e/ou ambientais e consequentes prejuízos econômicos e sociais. Os desastres são quantificados, em função dos danos e prejuízos, em termos de intensidade, enquanto os eventos adversos são quantificados em termos de magnitude".
} 
responsabilidade ambiental, consagrando, assim, a "regra da cumulatividade das sanções, até mesmo porque as sanções penais, civis e administrativas, além de protegerem objetos distintos, estão sujeitas a regimes jurídicos diversos" (Fiorillo, 2014, p. 140 ), conforme se depreende do parágrafo $3^{\circ}$ do artigo 225. In verbis: "As condutas e atividades consideradas lesivas ao meio ambiente sujeitarão os infratores, pessoas físicas ou jurídicas, a sanções penais e administrativas, independentemente da obrigação de reparar os danos causados" (BRASIL, 1988).

Na esfera ambiental, portanto, um dano pode gerar a seu causador responsabilidade criminal, civil e administrativa, sem que a punição em duas ou até mesmo nas três esferas configure bis in idem. É importante ressaltar, porém, que a tríplice responsabilidade ambiental é permitida, mas não necessária. Ou seja, somente haverá sanção em todas as esferas se o fato configurar infração administrativa e infração penal e também gerar o dever de indenizar.

Apesar de o Direito ser uno, ele é dividido em ramos relativamente independentes e com regras próprias. O Direito Ambiental é um ramo que está intimamente ligado a outros ramos, como Penal, Civil e Administrativo. Cada uma dessas esferas possui regras que devem ser observadas na responsabilização do poluidor ${ }^{2}$ e que são independentes entre si. Por isso, a absolvição ou condenação em uma esfera, em regra, não implicam o mesmo resultado nas outras.

Nosso trabalho visa a estudar cada uma dessas esferas a partir da análise da jurisprudência dos tribunais superiores e tendo como pano de fundo as responsabilidades aplicadas ao caso Samarco.
Em que pese não termos tido acesso aos processos ora em andamento, as informações oficiais prestadas pelo IBAMA, pelo Ministério do Meio Ambiente (MMA), pelo Ministério Público Federal (MPF) e pela Polícia Federal (PF) nos permitem analisar as possíveis consequências jurídicas desse caso e identificar, com muito boa precisão, as esferas de responsabilidade a que a Samarco e suas controladoras deverão se sujeitar.

\section{O dano ambiental}

Antes de se analisar a responsabilidade de quem dá causa a um dano ambiental, é necessário entender o que é esse dano ambiental.

Em que pese a legislação brasileira utilizar o termo "dano ambiental" em diversos dispositivos, não existe uma definição legal para ele, cabendo à doutrina o papel de conceituá-lo. Segundo Milaré (2014, p. 320):

\begin{abstract}
É dano ambiental toda interferência antrópica infligida ao patrimônio ambiental (natural, cultural, artificial) capaz de desencadear, imediata ou potencialmente, perturbações desfavoráveis (in pejus) ao equilíbrio ecológico, à sadia qualidade de vida, ou a quaisquer outros valores coletivos ou de pessoas.
\end{abstract}

Já para Antunes (2005, p. 203), “dano ambiental é dano ao meio ambiente", considerando-se que, nos termos da Política Nacional do Meio Ambiente, "meio ambiente [é] o conjunto de condições, leis, influências e interações de ordem física, química e biológica, que permite, abriga e rege a vida em todas as suas formas" (Brasil. Lei 6.938, 1981, artigo $3^{\circ}$, inciso I). O dano ambiental é, portanto,

\footnotetext{
${ }^{2}$ Considera-se poluidor a "pessoa física ou jurídica, de direito público ou privado, responsável, direta ou indiretamente, por atividade causadora de degradação ambiental", nos termos do artigo $3^{\circ}$, IV, da Lei 6.938/81.
} 
qualquer prejuízo causado ao meio ambiente em decorrência de uma ação ou omissão humana, e seu causador deve ser responsabilizado, podendo responder no âmbito de três esferas, conforme será a seguir analisado.

\section{Responsabilidade penal}

O Direito Penal é um poderoso instrumento do Estado contra o cidadão, responsável pela aplicação de sanção a quem pratica infração penal. Apesar de haver a possibilidade de aplicação de penas restritivas de direito e multa, esse ramo do Direito é o único capaz de impor a alguém a privação de sua liberdade como forma de sanção, já que a prisão civil é de curta duração e tem caráter coercitivo. E, em razão desse alto grau de ameaça a um direito fundamental e "valor supremo para a vida em sociedade" (Milaré, 2014) - a liberdade -, o Direito Penal deve ser utilizado de forma cautelosa:

Toda condenação penal, especialmente quando esta atinge a liberdade da pessoa, estigmatiza o indivíduo e repercute negativamente em seu senso de dignidade, razão pela qual o Direito Penal há de ser minimamente usado (Milaré, 2014, p. 463).

E, para orientar a utilização cautelosa do Direito Penal, tanto na edição de normas quanto na aplicação destas, esse ramo é regido por alguns princípios, como o da intervenção mínima e o da fragmentariedade. Segundo aquele princípio, o Direito Penal só deve ser aplicado como ultima ratio, ou seja, em última hipótese, quando nenhum outro ramo do Direito se mostrar suficiente. Assim, se uma sanção civil ou administrativa for suficiente para punir uma conduta, não deverá haver sanção penal.

Para determinar quais condutas merecem a atenção do Direito Penal, utiliza-se o Princípio da fragmentariedade, que seleciona os bens jurídicos mais relevantes e as lesões que os acometem, de forma a prever a aplicação de sanção penal somente a algumas lesões: aquelas que não podem ser de outra forma suficientemente punidas, conforme explica Lecey (2013, p. 395):

\begin{abstract}
Por suas repercussões em tais direitos fundamentais explicitamente garantidos pela Constituição, de forma implícita, temos como princípio penal o da mínima intervenção do Direito Penal. Assim, somente haverá reserva legal, somente sofrerá incidência de norma incriminadora, a conduta que apresenta lesividade, de conformidade com outro princípio penal básico. Ou seja, apenas a conduta que ofender ou colocar em perigo de ofensa um bem jurídico merecerá a mínima intervenção do Direito Criminal. E não é qualquer bem que terá a tutela do Direito Penal. Tão somente aqueles de extrema relevância social, a ponto de merecerem a mais severa sanção, como é a criminal. Tudo na linha do conhecido Direito Penal Mínimo, ou do Direito Penal Necessário.
\end{abstract}

A intervenção do Direito Penal no Direito Ambiental justifica-se pelo fato de o meio ambiente equilibrado ser um direito fundamental de todos e bem jurídico essencial à existência humana no planeta Terra. Ademais, a própria Constituição Federal estabeleceu que algumas ofensas ao meio ambiente deveriam gerar a responsabilidade criminal do infrator (preceito incriminador do artigo 225, $\S 3^{\circ}$ da Constituição). ${ }^{3}$

\footnotetext{
${ }^{3}$ Algo que foi bem explicado pelo Ministro do STF Gilmar Mendes, em seu voto na Ação Penal 439-1/SP: "A norma penal protege o valor fundamental do meio ambiente ecologicamente equilibrado, bem de uso comum do povo e essencial à sadia qualidade de vida, assegurado pelo art. 225 da Constituição da República. A finalidade do Direito Penal é justamente conferir uma proteção reforçada aos valores fundamentais
} 
Em razão dessas características do Direito Penal, a responsabilidade penal é subjetiva, inclusive no âmbito das infrações penais ambientais, sendo inadmissível, no Direito brasileiro, a responsabilidade penal objetiva. Portanto, só responde criminalmente quem praticou a conduta típica dolosa ou culposamente se houver previsão legal. Nas palavras de Vania Samira Doro Pereira, "é imprescindível a existência de elemento subjetivo (consistente no dolo ou na culpa) que ligue a conduta do agente ao resultado causado para que haja tanto a configuração do delito quanto a imposição de pena" (Pereira, 2012, p. 9). No caso da Samarco e do desastre ambiental em Mariana, a responsabilidade criminal pelo dano decorreria de imprudência de funcionários, ou da decisão deliberada da direção da pessoa jurídica de não promover ações de segurança. O rompimento das barragens pode ser considerado consequência da incúria da empresa em não gastar com precauções.

No âmbito jurisprudencial, a principal mudança no entendimento dos tribunais superiores ocorreu em relação à obrigatoriedade ou não da dupla imputação em caso de responsabilidade penal da pessoa jurídica.

Segundo a Constituição Federal, "as condutas e atividades consideradas lesivas ao meio ambiente sujeitarão os infratores, pessoas físicas ou jurídicas, a sanções penais e administrativas, independentemente da obrigação de reparar os danos causados"
(Brasil. Constituição, 1998, artigo 225, § $3^{\circ}$ ). A Carta Magna inovou, pois, ao admitir a responsabilidade penal da pessoa jurídica, que foi disciplinada pela Lei 9.605/98.

Apesar de nem a lei nem a Constituição Federal vincularem a responsabilidade da pessoa jurídica à da pessoa física, parte da doutrina, bem como o Superior Tribunal de Justiça (STJ), adotava a Teoria da Dupla Imputação Necessária, segundo a qual a pessoa jurídica somente poderia integrar o polo passivo de uma ação em litisconsórcio necessário com uma pessoa física, conforme se depreende do voto da Ministra Maria Thereza de Assis Moura no Recurso em Mandado de Segurança n ${ }^{\circ}$ 27.593-SP:

Com efeito, esta Corte assentou o entendimento no sentido de que, nos crimes ambientais, é necessária a dupla imputação, pois não se admite a responsabilização penal da pessoa jurídica dissociada da pessoa física, que age com elemento subjetivo próprio.

Em 2013, porém, o Supremo Tribunal Federal (STF) rechaçou a Teoria da Dupla Imputação Necessária, passando a admitir que a pessoa jurídica deveria integrar sozinha o polo passivo da ação penal. Segundo a Ministra Rosa Weber, a "Constituição Federal não condiciona a responsabilização penal da pessoa jurídica por crimes ambientais à simultânea persecução penal da pessoa física" e, diante da complexidade das organizações, esse condicionamento seria uma "indevida restrição da

compartilhados culturalmente pela sociedade. Além dos valores clássicos, como a vida, liberdade, integridade física, honra e imagem, patrimônio, etc., o Direito Penal, a partir de meados do século XX, passou a cuidar também do meio ambiente, que ascendeu paulatinamente ao posto de valor supremo das sociedades contemporâneas, passando a compor o rol de direitos fundamentais ditos de $3^{\mathrm{a}}$ geração incorporados nos textos constitucionais dos Estados Democráticos de Direito. Parece certo, por outro lado, que essa proteção pela via do Direito Penal justifica-se apenas em face de danos efetivos ou potenciais ao valor fundamental do meio ambiente; ou seja, a conduta somente pode ser tida como criminosa quando degrade ou no mínimo traga algum risco de degradação do equilíbrio ecológico das espécies e dos ecossistemas. Fora dessas hipóteses, o fato não deixa de ser relevante para o Direito. Porém, a responsabilização da conduta será objeto do Direito Administrativo ou do Direito Civil. O Direito Penal atua, especialmente no âmbito da proteção do meio ambiente, como ultima ratio, tendo caráter subsidiário em relação à responsabilidade civil e administrativa de condutas ilegais. Esse é o sentido de um Direito Penal mínimo, que se preocupa apenas com os fatos que representam graves e reais lesões a bens e valores fundamentais da comunidade". 
norma constitucional" (Brasil. Supremo Tribunal Federal, 2013. Julgamento do Recurso Extraordinário $\left.{ }^{0} 548.181 / \mathrm{PR}\right){ }^{4}$

Com essa decisão do STF, o STJ mudou seu entendimento e não mais adota a Teoria da Dupla Imputação Necessária. Vale ressaltar, porém, que a pessoa jurídica somente pode ser responsabilizada se o crime tiver sido praticado em seu benefício, conforme explica o Ministro Reynaldo Soares da Fonseca no julgamento do Recurso Ordinário em Habeas Corpus no 64.219-MS (2015/0242101-4):

A Lei dos Crimes Ambientais ( $\mathrm{n}^{\circ}$ 9.605/1998) estabelece que: "Art. $3^{\circ}$ As pessoas jurídicas serão responsabilizadas administrativa, civil e penalmente conforme o disposto nesta Lei, nos casos em que a infração seja cometida por decisão de seu representante legal ou contratual, ou de seu órgão colegiado, no interesse ou benefício da sua entidade. Parágrafo único. A responsabilidade das pessoas jurídicas não exclui a das pessoas físicas, autoras, coautoras ou partícipes do mesmo fato".

Assim, conforme o mencionado regramento, as pessoas jurídicas serão responsabilizadas nos âmbitos administrativo, civil e penal quando a infração cometida resulte de decisão de seu representante legal ou contratual, ou de seu órgão colegiado, no interesse ou benefício de sua entidade, ressalvando-se que a responsabilização da pessoa jurídica não exclui a responsabilidade das pessoas físicas, autoras, coautoras ou partícipes do mesmo fato (Brasil. Superior Tribunal de Justiça, 2015. Julgamento do Recurso Ordinário em Habeas Corpus no 64.219-MS).

\section{Conforme já destacado, o Direito Penal} deve ser mínimo, pois é o único capaz de limitar a liberdade da pessoa por meio das penas privativas de liberdade e essa restrição é, em qualquer circunstância, extremamente agressiva, devendo, portanto, ser utilizada de modo excepcional e supletivo. Todavia, nem todas as sanções penais se restringem à pena privativa de liberdade. Às pessoas jurídicas, por exemplo, as penas aplicáveis são: i - multa; ii - restritivas de direitos (suspensão parcial ou total de atividades; interdição temporária de estabelecimento, obra ou atividade; proibição de contratar com o Poder Público, bem como dele obter subsídios, subvenções ou doações) $)^{5}$; e iii - prestação de serviços à comunidade. ${ }^{6}$ Portanto, a inviabilidade de se restringir a liberdade da pessoa jurídica não impede sua responsabilização no âmbito penal, já que outras sanções são a ela aplicáveis.

\begin{abstract}
4 “BRASIL. Supremo Tribunal Federal. Julgamento do Recurso Extraordinário n 548181/PR. Relatora: Ministra Rosa Weber. RECURSO EXTRAORDINÁRIO. DIREITO PENAL. CRIME AMBIENTAL. RESPONSABILIDADE PENAL DA PESSOA JURÍDICA. CONDICIONAMENTO DA AÇÃO PENAL À IDENTIFICAÇÃO E À PERSECUÇÃO CONCOMITANTE DA PESSOA FÍSICA QUE NÃO ENCONTRA AMPARO NA CONSTITUIÇÃO DA REPÚBLICA. $1 . \mathrm{O}$ art. $225, \S 3^{\circ}$, da Constituição Federal não condiciona a responsabilização penal da pessoa jurídica por crimes ambientais à simultânea persecução penal da pessoa física em tese responsável no âmbito da empresa. A norma constitucional não impõe a necessária dupla imputação. 2. As organizações corporativas complexas da atualidade se caracterizam pela descentralização e distribuição de atribuições e responsabilidades, sendo inerentes, a esta realidade, as dificuldades para imputar o fato ilícito a uma pessoa concreta. 3. Condicionar a aplicação do art. $225, \S 3^{\circ}$, da Carta Política a uma concreta imputação também a pessoa física implica indevida restrição da norma constitucional, expressa a intenção do constituinte originário não apenas de ampliar o alcance das sanções penais, mas também de evitar a impunidade pelos crimes ambientais frente às imensas dificuldades de individualização dos responsáveis internamente às corporações, além de reforçar a tutela do bem jurídico ambiental. 4. A identificação dos setores e agentes internos da empresa determinantes da produção do fato ilícito tem relevância e deve ser buscada no caso concreto como forma de esclarecer se esses indivíduos ou órgãos atuaram ou deliberaram no exercício regular de suas atribuições internas à sociedade, e ainda para verificar se a atuação se deu no interesse ou em benefício da entidade coletiva. Tal esclarecimento, relevante para fins de imputar determinado delito à pessoa jurídica, não se confunde, todavia, com subordinar a responsabilização da pessoa jurídica à responsabilização conjunta e cumulativa das pessoas físicas envolvidas. Em não raras oportunidades, as responsabilidades internas pelo fato estarão diluídas ou parcializadas de tal modo que não permitirão a imputação de responsabilidade penal individual. 5. Recurso Extraordinário parcialmente conhecido e, na parte conhecida, provido.”
\end{abstract}

${ }^{5}$ Nos termos do artigo 22 da Lei 9.605/98.

${ }^{6}$ Nos termos do artigo 23 da Lei 9.605/98. 
Pode-se afirmar, assim, que atualmente a jurisprudência é pacífica no que se refere à responsabilidade criminal por danos ambientais. Feitas as considerações gerais sobre esse assunto, passemos a analisar o caso concreto.

Segundo o Auto de Infração 19-E de 12/11/2015 do IBAMA, houve "carreamento de rejeito de mineração e perecimento de espécimes da biodiversidade (fauna e recursos pesqueiros) na área diretamente afetada e ao longo do rio Doce, em decorrência do rompimento da barragem de Fundão" (Ibama, 2015, p. 1), caracterizando-se o crime previsto no artigo 33 da Lei de Crimes Ambientais (LCA): "Provocar, pela emissão de efluentes ou carreamento de materiais, o perecimento de espécimes da fauna aquática existentes em rios, lagos, açudes, lagoas, baías ou águas jurisdicionais brasileiras" (Brasil. Lei 9.605, 1998, artigo 33).

O Auto de Infração 9082395-E de 12/11/2015 do IBAMA descreve a seguinte conduta: "Lançar resíduos sólidos e líquidos (rejeito de mineração de ferro) nas águas do rio Doce, em desacordo com as exigências estabelecidas em leis ou atos normativos" (Ibama, 2015, p. 1). Já o Auto de Infração 24-E de 12/11/2015 do IBAMA relata: "Causar poluição hídrica com carreamento de rejeitos de mineração procedentes do sistema de deposição da barragem Fundão, causando necessária interrupção do abastecimento público de água da comunidade do município de Governador Valadares/MG" (Ibama, 2015, p. 1).

E, por fim, o Auto de Infração 21-E de 12/11/2015 do IBAMA indica a seguinte conduta: "Causar poluição no rio Doce, nos estados de Minas Gerais e Espírito Santo, por meio do lançamento de rejeito de mineração de ferro, provocando a mor- tandade de animais ao longo do rio e resultando em risco à saúde humana" (Ibama, 2015, p. 1).

Dessas condutas pode restar caracterizado o crime do artigo 54 da LCA: "Causar poluição de qualquer natureza em níveis tais que resultem ou possam resultar em danos à saúde humana, ou que provoquem a mortandade de animais ou a destruição significativa da flora" (Brasil. Lei 9.605, 1998, artigo 54), duplamente qualificado pela "poluição hídrica que torne necessária a interrupção do abastecimento público de água de uma comunidade" (Brasil. Lei 9.605, 1998, artigo 54, § 2, inciso III) e por ser resultante de "lançamento de resíduos sólidos, líquidos ou gasosos, ou detritos, óleos ou substâncias oleosas, em desacordo com as exigências estabelecidas em leis ou regulamentos" (Brasil. Lei 9.605, 1998, artigo 54, § 2, inciso V). Nesse caso, pode haver, ainda, aumento da pena $^{7}$, visto que houve dano irreversível ao meio ambiente, bem como a morte de algumas pessoas.

A Samarco pode responder, também, pelo crime tipificado no artigo 69-A da LCA se restar comprovado que, durante o licenciamento (inicial ou renovação de licenças) das barragens, a empresa apresentou estudo, laudo ou relatório ambiental total ou parcialmente falso ou enganoso.

\section{Responsabilidade civil}

A responsabilidade civil é um instituto jurídico segundo o qual o causador do dano é obrigado a repará-lo. Em regra, este somente será obrigado a reparar o dano se for demonstrado que agiu com culpa lato sensu, ou seja, além de demonstrar conduta ilícita, dano e nexo causal entre eles, é necessário comprovar que a pessoa agiu com dolo,

\footnotetext{
${ }^{7}$ Nos termos do artigo 58 da Lei 9.605/98.
} 
imperícia, imprudência ou negligência. Nesse caso, a responsabilidade é subjetiva e está intimamente fundada na culpabilidade.

Porém, o próprio Código Civil faz duas ressalvas, permitindo que a reparação ocorra independentemente de culpa, bastando demonstrar o nexo de causalidade entre a conduta e o resultado. Nos termos do artigo 927 do mencionado diploma legal, a responsabilidade civil será objetiva "nos casos especificados em lei, ou quando a atividade normalmente desenvolvida pelo autor do dano implicar, por sua natureza, risco para os direitos de outrem" (Brasil. Código Civil, 2002, artigo 927, parágrafo único).

Apesar de não haver no Direito brasileiro um Código Ambiental, as leis que regulam o tema definem que a responsabilidade civil ambiental é objetiva. A Política Nacional de Meio Ambiente (PNMA - Lei 6.938/81), por exemplo, define expressamente que o poluidor é obrigado a reparar, independentemente de culpa:

Art. 14 - Sem prejuízo das penalidades definidas pela legislação federal, estadual e municipal, o não cumprimento das medidas necessárias à preservação ou correção dos inconvenientes e danos causados pela degradação da qualidade ambiental sujeitará os transgressores:

[...]

$\S 1^{\circ}$ - Sem obstar a aplicação das penalidades previstas neste artigo, é o poluidor obrigado, independentemente da existência de culpa, a indenizar ou reparar os danos causados ao meio ambiente e a terceiros, afetados por sua atividade. O Ministério Público da União e dos Estados terá legitimidade para propor ação de responsabilidade civil e criminal, por danos causados ao meio ambiente (Brasil. Lei 6.938, 1981, artigo 14, grifo nosso).

No mesmo sentido define a Política Nacional de Resíduos Sólidos (PNRS - Lei 12.305/2010):
Sem prejuízo da obrigação de, independentemente da existência de culpa, reparar os danos causados, a ação ou omissão das pessoas físicas ou jurídicas que importe inobservância aos preceitos desta Lei ou de seu regulamento sujeita os infratores às sanções previstas em lei (Brasil. Lei 12.305, 2010, artigo 51, grifo nosso).

Ajurisprudência também é pacífica no sentido de que a responsabilidade ambiental é objetiva:

O vazamento de óleo em águas marítimas impõe dois tipos de obrigações, a de fazer, consistente no dever de recuperar o meio ambiente afetado, e a de indenizar, sendo irrelevante a existência ou não de culpa, visto que a responsabilidade pelo dano ambiental, desde 1981, é objetiva, por força do disposto no art. 14, § $1^{\circ}$, da Lei da Política Nacional do Meio Ambiente. (BRASIL. Supremo Tribunal Federal, 2015. Agravo Regimental. Recurso Extraordinário com Agravo 808.356-SP. Relator: Ministro Dias Toffoli, Segunda Turma. Data do julgamento: 30/6/2015, grifo nosso).

A responsabilidade por dano ambiental é objetiva, informada pela teoria do risco integral, sendo o nexo de causalidade o fator aglutinante que permite que o risco se integre na unidade do ato, sendo descabida a invocação, pela empresa responsável pelo dano ambiental, de excludentes de responsabilidade civil para afastar a sua obrigação de indenizar [Brasil. Superior Tribunal de Justiça, 2014. Recurso Especial 1.354.536-SE (2012/0246647-8). Relator: Ministro Luis Felipe Salomão. Órgão julgador: S2 - Segunda Seção. Data do julgamento: 26/3/2014, grifo nosso].

Aquele que cria ou assume o risco de danos ambientais tem o dever de reparar os danos causados e, em tal contexto, transfere-se a ele todo o encargo de provar que sua conduta não foi lesiva (Brasil. Superior Tribunal de Justiça, 2009. Recurso Especial 1.049.822-RS. Relator: Ministro Francisco Falcão, Primeira Turma. Julgado em 23/4/2009, DJe, 18/5/2009).

Além de não analisar a culpabilidade do poluidor, essa esfera não admite qualquer excludente 
de responsabilidade, pois adota a Teoria do Risco Integral, como explica Giudice (2005, p. 28):

Havendo uma conduta - comissiva ou omissiva - e um dano, e se entre eles houver uma relação de causa e efeito, um liame causal que ligue a conduta do agente ao dano provocado, sobrevirá o dever de indenizar. Se já era dispensável a verificação de culpa na responsabilidade civil objetiva, nesta modalidade nenhum outro juízo de valor concernente à conduta do agente ou ao evento em que se verificou a ocorrência do dano será feito, nem mesmo quando restar comprovada a presença de algumas das excludentes de responsabilidade.

A esfera civil ambiental não busca sancionar o causador de um dano, mas tão somente recuperá-lo ou indenizá-lo, visto que o meio ambiente equilibrado é um direito fundamental e qualquer dano a ele deve ser imediatamente reparado. Como ressaltou o Ministro do STJ Luis Felipe Salomão no julgamento do Recurso Especial 2012/0246647-8, “é inadequado pretender conferir à reparação civil dos danos ambientais caráter punitivo imediato, pois a punição é função que incumbe ao direito penal e administrativo".

Por isso, além de objetiva, a responsabilidade civil ambiental é solidária e propter rem. ${ }^{8}$ Vejamos.

Nos termos do artigo 265 do Código Civil (Brasil, 2002), "a solidariedade não se presume; resulta da lei ou da vontade das partes". Porém, apesar de não haver no Direito Ambiental brasileiro expressa previsão legal, uma interpretação lógico-sistemática do ordenamento jurídico vigente, ou seja, uma análise de todas as normas inter-relacionadas para entender o sentido e o alcance de cada uma nos permite concluir que a responsabilidade ambiental é solidária. Contribuem para essa interpretação o artigo 225 da Constituição Federal (Brasil, 1988) e os artigos $3^{\circ}, 4^{\circ}$ e 14 da PNMA (Brasil. Lei 6.938, 1981). In verbis:

Art. 225. Todos têm direito ao meio ambiente ecologicamente equilibrado, bem de uso comum do povo e essencial à sadia qualidade de vida, impondo-se ao Poder Público e à coletividade o dever de defendê-lo e preservá-lo para as presentes e futuras gerações (grifo nosso).

Art. $3^{\circ}$ - Para os fins previstos nesta Lei, entende-se por:

$[\ldots]$

IV - poluidor a pessoa física ou jurídica, de direito público ou privado, responsável, direta ou indiretamente, por atividade causadora de degradação ambiental;

Art. $4^{\circ}$ - A Política Nacional do Meio Ambiente visará:

$[\ldots]$

VII - à imposição, ao poluidor e ao predador, da obrigação de recuperar elou indenizar os danos causados, e ao usuário, de contribuição pela utilização de recursos ambientais com fins econômicos.

Art. 14 - Sem prejuízo das penalidades definidas pela legislação federal, estadual e municipal, o não cumprimento das medidas necessárias à preservação ou correção dos inconvenientes e danos causados pela degradação da qualidade ambiental sujeitará os transgressores:

[...]

$\S 1^{\circ}$ Sem obstar a aplicação das penalidades previstas neste artigo, é o poluidor obrigado, independentemente da existência de culpa, a indenizar ou reparar os danos causados ao meio ambiente e a terceiros, afetados por sua atividade. O Ministério Público da União e dos Estados terá legitimidade para

\footnotetext{
${ }^{8}$ Obrigação vinculada a um direito real. Se o proprietário transferir o bem para outro, a obrigação permanece vinculada ao bem, sendo responsável pela obrigação o novo proprietário e não o antigo.
} 
propor ação de responsabilidade civil e criminal, por danos causados ao meio ambiente (grifos nossos). a fim de garantir uma real, mais eficaz e mais rápida reparação integral do dano.
Ou seja, cada um dos poluidores responde pela reparação integral do dano e "o lesado pode demandar contra um, parte ou todas as pessoas envolvidas na produção do dano. Cabe, via de regra, à pessoa que pagar o dano ao lesado, ação regressiva contra os demais solidários, cada qual na medida de sua responsabilidade" (Machado, 2010, p. 694). Lucarelli (1994, p. 83) explica a necessidade de se estabelecer a solidariedade na responsabilidade civil ambiental:

[Dado o] caráter de ordem pública de que goza a proteção do meio ambiente, institui-se a solidariedade passiva pela reparação do dano ecológico, o que significa dizer que, por exemplo, em um distrito industrial onde seja possível individualizar-se o responsável pelo dano ambiental, todos serão solidariamente responsáveis. Essa responsabilidade passiva visa atender ao interesse público de ser totalmente reparado o prejuízo causado, constituindo-se faculdade do credor vítima da poluição a escolha de mover o processo contra este ou aquele devedor, podendo escolher todos ou o que goza de melhor situação financeira. [...] É, sobretudo, o interesse público que faz com que haja a solidariedade entre os degradadores do ambiente,
O Ministro do STJ Herman Benjamin, no julgamento do Agravo em Recurso Especial 432.409. RJ, em 25/2/2014, reforçando o entendimento do STJ, enfatiza que o litisconsórcio é facultativo, pois a responsabilidade civil é solidária:

\begin{abstract}
No dano ambiental e urbanístico, a regra geral é a do litisconsórcio facultativo. Segundo a jurisprudência do STJ, nesse campo a "responsabilidade (objetiva) é solidária" (REsp 604.725/PR, Rel. Ministro Castro Meira, Segunda Turma, DJ 22.8.2005, p. 202); logo, mesmo havendo "múltiplos agentes poluidores, não existe obrigatoriedade na formação do litisconsórcio", abrindo-se ao autor a possibilidade de "demandar de qualquer um deles, isoladamente ou em conjunto, pelo todo" (Brasil, Superior Tribunal de Justiça, 2010. Recurso Especial 880.160-RJ. Relator: Ministro Mauro Campbell Marques, Segunda Turma, DJe 27/5/2010, grifo nosso).
\end{abstract}

A responsabilidade civil ambiental, portanto, é objetiva, solidária e propter rem, como bem explica o Ministro Herman Benjamin em seu voto no Recurso Especial n ${ }^{\circ} 1.186 .130-R J$ (Brasil. Superior Tribunal de Justiça, 2010): ${ }^{9}$

\footnotetext{
${ }^{9}$ Ministro Herman Benjamin em seu voto no Recurso Especial n ${ }^{\circ} 1.186 .130$-RJ: "No mérito, porém, entendo que o acórdão recorrido não adotou a melhor solução jurídica para a controvérsia. [...] In casu, é incontroverso que a obra foi construída em área de proteção ambiental non aedificandi e que os representantes legais da empresa são os proprietários do imóvel degradado, assim como a ré ocupava o local à época da ocorrência da infração ambiental. Conforme a jurisprudência firmada nesta Corte, as obrigações derivadas de degradação ambiental são de natureza propter rem, o que significa dizer que aderem ao título e se transferem ao futuro proprietário, mais ainda se o ilícito beneficia ou valoriza o terreno, prescindindo-se de debate sobre a boa ou má-fé do adquirente, pois não se está na condição de responsabilidade subjetiva, baseada em culpa. Confiram-se os precedentes: AMBIENTAL. EMBARGOS DE DECLARAÇÃO CONHECIDOS COMO AGRAVO REGIMENTAL. PRINCÍPIOS DA FUNGIBILIDADE RECURSAL E DA ECONOMIA PROCESSUAL. DANO AMBIENTAL EM RESERVA LEGAL. DEVER DE RECUPERAÇÃO. OBRIGAÇÃO “PROPTER REM”. ABRANGÊNCIA DO PROPRIETÁRIO ATUAL, INDEPENDENTE DE QUEM CAUSOU O DANO. 1. É de se conhecer dos embargos de declaração como agravo regimental, em razão de seu caráter nitidamente infringente, em prestígio aos princípios da fungibilidade recursal e economia processual. 2. O entendimento do Superior Tribunal de Justiça é no sentido de que (i) a averbação da reserva legal, no âmbito do Direito Ambiental, tem caráter meramente declaratório e (ii) a obrigação de recuperar a degradação ambiental ocorrida na faixa da reserva legal abrange aquele que é titular da propriedade do imóvel, mesmo que não seja de sua autoria a deflagração do dano, tendo em conta sua natureza propter rem. [...] Desse modo, a realização do aterro e construção irregular em faixa de proteção marginal, por terceira pessoa, não isenta o proprietário da área, que pode - e deve - ser responsabilizado não apenas por aquilo que fez, como também pela omissão ao não impedir ou deixar de levar imediatamente ao conhecimento das autoridades a violação da lei, que, praticada
} 
Conforme a jurisprudência firmada nesta Corte, as obrigações derivadas de degradação ambiental são de natureza propter rem, o que significa dizer que aderem ao título e se transferem ao futuro proprietário, mais ainda se o ilícito beneficia ou valoriza o terreno, prescindindo-se de debate sobre a boa ou má-fé do adquirente, pois não se está na condição de responsabilidade subjetiva, baseada em culpa.

$[\ldots]$

Para o fim de apuração do nexo de causalidade no dano ambiental, equiparam-se quem faz, quem não faz quando deveria fazer, quem deixa fazer, quem não se importa que façam, quem financia para que façam, quem cala quando tinha o dever de denunciar, e quem se beneficia quando outros fazem.

Configura-se, portanto, a ofensa ao art. $14, \S 1^{\circ}$, da Lei 6.938/1981. Constatado o nexo causal entre a omissão da recorrida e o dano ambiental em questão, surge, objetivamente, o dever de promover a recuperação da área afetada.

$\mathrm{Na}$ esfera civil, o dano causado ao rio Doce pela Samarco foi comprovado por meio dos relatórios técnicos do IBAMA, bem como restou identificado o nexo de causalidade entre a conduta da Samarco (proprietária das barragens de onde os rejeitos foram lançados) e o dano ambiental. Considerando que a responsabilidade é objetiva e não admite excludentes, cabe à causadora do dano o dever de reparação, e, para tanto, já firmou TACs. Contudo, como tal dever de reparação é integral, entendemos que qualquer limitação ao dever de reparar os danos causados deve ser considerada ilícita. Nesse sentido, o TAC assinado deve ser entendido muito mais como o início das necessárias ações de restauração dos biomas atingidos, até sua completa recuperação.

\section{Responsabilidade administrativa}

Já a responsabilidade administrativa ambiental possui diversas discussões acerca da necessidade de se comprovar a culpa lato sensu do infrator. Para a primeira corrente, a responsabilidade administrativa ambiental é subjetiva, pois os dispositivos legais ambientais que tratam da responsabilidade objetiva referem-se tão somente ao dever de indenizar, ou seja, à responsabilidade civil pelo dano ambiental. Ademais, a responsabilidade administrativa, em regra, é subjetiva, pois se refere a infrações, podendo ser objetiva apenas se houver expressa disposição legal nesse sentido.

por terceiros, acabaria por beneficiá-lo. Para o fim de apuração do nexo de causalidade no dano ambiental, equiparam-se quem faz, quem não faz quando deveria fazer, quem deixa fazer, quem não se importa que façam, quem financia para que façam, quem cala quando tinha o dever de denunciar, e quem se beneficia quando outros fazem. Configura-se, portanto, a ofensa ao art. $14, \S 1^{\circ}$, da Lei 6.938/1981. Constatado o nexo causal entre a omissão da recorrida e o dano ambiental em questão, surge, objetivamente, o dever de promover a recuperação da área afetada. Nesse sentido: PROCESSUAL CIVIL E ADMINISTRATIVO - VIOLAÇÃO DO ART. 535 DO CPC NÃO CARACTERIZADA - DANO AMBIENTAL - RESPONSABILIDADE OBJETIVA - AUSÊNCIA DE NEXO - REEXAME DE PROVAS: SÚMULA 7/STJ - ARTS. $4^{\circ}$, VII E 14 DA LEI 6.938/81 - RECUPERAÇÃO NATURAL DA NATUREZA - AUSÊNCIA DE INDENIZAÇÃO - DISPOSITIVOS APONTADOS COMO VIOLADOS INSUFICIENTES PARA AMPARAR A PRETENSÃO DA RECORRENTE. 1. Não ocorre ofensa ao art. 535, II, do CPC, se o Tribunal de origem decide, fundamentadamente, as questões essenciais ao julgamento da lide. 2. É inadmissível o recurso especial se a análise da pretensão da recorrente demanda o reexame de provas. 3. A interpretação dos dispositivos legais apontados como violados pela recorrente não se apresenta suficiente para amparar a pretensão deduzida pela recorrente, no tocante a ausência de condenação pecuniária quando ocorre a recuperação natural do meio ambiente. 4. Nos termos do $\S 1^{\circ}$, art. 14 da lei 6.938 de 1991 , é o poluidor obrigado, independentemente de culpa, a indenizar ou reparar os danos causados ao meio ambiente. 5. Recurso especial parcialmente conhecido e, nessa parte, não provido. (REsp 1045746/RS, Rel. Ministra Eliana Calmon, Segunda Turma, DJe 04/08/2009, grifei). [...]. Conclui-se que o acórdão recorrido está em desacordo com a jurisprudência do Superior Tribunal de Justiça sobre essa questão, razão pela qual merece reforma. Em síntese, o proprietário de imóvel que nele permite, por ação ou omissão, a realização de atividades ou obras por terceiro responde solidariamente pela eventual degradação ambiental, pois incumbe-lhe zelar pela sua conservação, podendo, assim, figurar no polo passivo de demanda que visa à demolição das construções e a benfeitorias irregulares, sobretudo quando estas acabam por favorecê-lo ou valorizar o terreno." 
Já a segunda corrente defende que a responsabilidade administrativa ambiental é objetiva em razão do interesse público de preservação do meio ambiente e da necessidade de rápida reparação do dano, o que seria dificultado em eventual discussão sobre a presença ou não de culpa. Porém, diferentemente da responsabilidade objetiva, que adotou a Teoria do Risco Integral, a responsabilidade administrativa admite excludentes - fato de terceiro, caso fortuito ou força maior.

A responsabilidade ambiental administrativa é regulada pela Lei 9.605/98 (Capítulo VI), que é omissa quanto à regra geral, referindo-se à necessidade da presença do elemento culpa somente para aplicação da multa simples. Assim, alguns doutrinadores, como Machado (2012, p. 374), afirmam que a ausência de expressa previsão legal nas demais sanções torna desnecessária a apuração de existência de culpa:

Das 10 sanções previstas no art. 72 da Lei 9.605/1998 (incisos I a XI), somente a multa simples utilizará o critério da responsabilidade com culpa; e as outras nove sanções, inclusive a multa diária, irão utilizar o critério da responsabilidade sem culpa ou objetiva, continuando a seguir o sistema da lei 6.938/1981, onde não há necessidade de serem aferidos o dolo e a negligência do infrator submetido ao processo.

Diante dessa divergência na doutrina, a análise da jurisprudência dos tribunais superiores se reveste de maior relevância.

Apesar de não haver um entendimento pacificado em relação à matéria, evidenciado pela ausência de decisões unânimes sobre o assunto, é possível afirmar que o entendimento majoritário do Superior Tribunal de Justiça é no sentido de que a responsabilidade ambiental administrativa é objetiva, conforme se depreende do voto do Ministro Benedito Gonçalves, no julgamento do Recurso Especial n ${ }^{\circ}$ 1.318.051-RJ:
Pois bem, ao contrário do entendimento da recorrente, é objetiva a responsabilidade administrativa ambiental. Deveras, esse preceito foi expressamente inserido no nosso ordenamento com a edição da Lei de Política Nacional do Meio Ambiente (Lei ${ }^{\circ}$ $6.938 / 1981)$. Tanto é assim que o $\S 1^{\circ}$ do art. 14 do diploma em foco define que o poluidor é obrigado, sem que haja a exclusão das penalidades, a indenizar ou reparar os danos, independentemente da existência de culpa (Brasil. Superior Tribunal de Justiça, 2012).

Porém, no que se refere à responsabilidade do terceiro, a divergência é ainda maior. Alguns juristas que defendem a responsabilidade administrativa ambiental objetiva entendem que essa objetividade está restrita ao causador direto do dano, respondendo o terceiro apenas se comprovada sua culpa, ou seja, a responsabilidade do terceiro seria subjetiva, como explica a Ministra Regina Helena Costa no julgamento do Agravo em Recurso Especial $n^{\circ}$ 62.584-RJ (2011/0240437-3):

A responsabilidade objetiva, em matéria ambiental, não se transmite a terceiro, uma vez que este integra outra relação jurídica; nessa hipótese, a sua responsabilidade é subjetiva. Somente aquele que é o direto agente causador do dano pode ser responsabilizado objetivamente pela degradação ambiental, nesse caso o transportador do produto. O terceiro, proprietário da carga transportada, por não ser o efetivo causador do dano ambiental, é responsabilizado subjetivamente pela lesão pelo transportador [...]

Assim, as sanções administrativas alcançam tão somente aquele que, de fato, praticar a conduta causadora da lesão ambiental, vedada a punição de terceiros, o que somente seria possível se comprovado o nexo causal entre sua conduta e o acidente. Desse modo, em que pese a responsabilidade civil ambiental ser objetiva, entendo que a responsabilização administrativa de terceiro, proprietário da carga, por acidente ambiental causado pelo transportador, insere-se no regime geral da responsabilidade do direito brasileiro, revestindo, portanto, caráter subjetivo (Brasil. Superior Tribunal de Justiça, 2011, grifo nosso). 
Pois bem, segundo o artigo 70 da Lei 9.605/98, considera-se infração administrativa ambiental toda ação ou omissão que viole as regras jurídicas de uso, gozo, promoção, proteção e recuperação do meio ambiente. E o Decreto $n^{0}$ 6.514/08 dispõe sobre as infrações e sanções administrativas ao meio ambiente.

Algumas condutas tipificadas pela LCA também configuram infração administrativa, sujeitando o infrator a sanções também na esfera administrativa. Assim, além de poder responder na esfera penal, a Samarco será responsabilizada administrativamente pela morte de espécimes da fauna silvestre do rio Doce ${ }^{10}$, pela destruição da vegetação natural de área de preservação permanente (margens do rio Doce $)^{11}$ e pela poluição do rio, o que resultou em danos à saúde humana, mortandade de animais e destruição significativa da biodiversidade. ${ }^{12}$

No âmbito administrativo, a Samarco poderá, ainda, ser responsabilizada por apresentar informação, estudo, laudo ou relatório ambiental total ou parcialmente falso, enganoso ou omisso ${ }^{13}$ e por operar as barragens de Fundão e Santarém sem as devidas licenças ambientais ${ }^{14}$, bastando, para tanto, que tais condutas sejam comprovadas.

\section{Conclusão}

A tragédia ambiental em Mariana tomou conta dos noticiários brasileiros e reacendeu a discussão sobre as atitudes dos cidadãos, governos e empresas em relação ao meio ambiente, bem como as responsabilidades dos causadores de danos ambientais.

Analisando a doutrina e, em especial, a jurisprudência dos tribunais superiores, pudemos concluir que não há divergências em relação às responsabilidades civil e penal. Enquanto a primeira é objetiva, não admite excludentes (Teoria do Risco Integral), solidária e propter rem, visando tão somente à reparação do dano e não à punição do poluidor, a segunda é subjetiva e visa exclusivamente à punição de quem efetivamente deu causa ao dano. Já em relação à responsabilidade administrativa, não há um entendimento pacificado, mas a análise dos julgados do Superior Tribunal de Justiça nos permite afirmar que a maioria entende que a responsabilidade administrativa ambiental é objetiva, sendo subjetiva somente em relação a terceiros.

Por fim, um exame mais apurado das informações oficiais sobre o rompimento das barragens da mineradora Samarco em Mariana (MG) nos permite afirmar que a empresa responderá civilmente, devendo indenizar os danos causados ao rio Doce e seu entorno. Administrativamente, responderá por três infrações, estando sujeita à análise de outras duas possíveis infrações administrativas. No âmbito penal, não é possível afirmar se ela será apenada ou não, visto que é necessária a apuração da culpabilidade da empresa, porém elencamos os crimes nos quais ela pode se enquadrar.

\footnotetext{
${ }^{10}$ Nos termos do artigo 24 do Decreto 6.514/08.

${ }^{11}$ Nos termos do artigo 43 do Decreto 6.514/08.

${ }^{12}$ Nos termos do artigo 61 do Decreto 6.514/08.

${ }^{13}$ Nos termos do artigo 82 do Decreto 6.514/08.

${ }^{14}$ Nos termos do artigo $2^{\circ}$ da Resolução Conama 237/97.
} 


\section{Referências}

Antunes, P. B. Direito ambiental. 8. ed. Rio de Janeiro: Lumen Juris, 2005.

Brasil. Constituição Federal de 05 de outubro de 1988.

Brasil. Decreto 6.514/08, de 22 de julho de 2008. Dispõe sobre as infrações e sanções administrativas ao meio ambiente, estabelece o processo administrativo federal para apuração destas infrações, e dá outras providências. DOU de 23/07/2008.

Brasil. Lei $n .{ }^{\circ}$ 6.938/81, de 31 de agosto de 1981. Dispõe sobre a Política Nacional do Meio Ambiente, seus fins e mecanismos de formulação e aplicação, e dá outras providências. DOU de 02/09/1981.

Brasil. Lei $n .{ }^{\circ}$ 9.605/98, de 12 de fevereiro de 1998. Dispõe sobre as sanções penais e administrativas derivadas de condutas e atividades lesivas ao meio ambiente, e dá outras providências. DOU de 17/02/1998.

Brasil. Lei $n .^{\circ} 10.406$, de 10 de janeiro de 2002. Institui o Código Civil. Brasília: DOU de 11/1/2002

Brasil. Lei $n .{ }^{\circ}$ 12.305/10, de 2 de agosto de 2010. Institui a Política Nacional de Resíduos Sólidos; altera a Lei no 9.605, de 12 de fevereiro de 1998; e dá outras providências. DOU de 03/08/2010.

CONAMA - Conselho Nacional do Meio Ambiente. Resolução $n .^{\circ}$ 237, de 19 de dezembro de 1997. Brasília: DOU de 22/12/1997.

Fiorillo, C. A. P. Curso de direito ambiental brasileiro. 15. ed. São Paulo: Saraiva, 2014.

Giudice, B. M. Teoria do Risco Integral no Dano Ambiental. Rio de Janeiro - PUC, 2005.

IBAMA - Instituto Brasileiro do Meio Ambiente e dos Recursos Naturais Renováveis. Auto de Infração 19. Disponível em: <http://www.ibama.gov.br/phocadownload/ noticias_ambientais/auto_infracao_samarco_02.pdf.> Acesso em: abr. 2016.

IBAMA - Instituto Brasileiro do Meio Ambiente e dos Recursos Naturais Renováveis. Auto de Infração 9082395. Disponível em: $<$ http://www.ibama.gov.br/phocadownload/noticias_ambientais/auto_infracao_samarco_03.pdf.> Acesso em: abr. 2016.
IBAMA - Instituto Brasileiro do Meio Ambiente e dos Recursos Naturais Renováveis. Auto de Infração 24. Disponível em: <http://www.ibama.gov.br/phocadownload/ noticias_ambientais/auto_infracao_samarco_04.pdf.> Acesso em: abr. 2016.

IBAMA - Instituto Brasileiro do Meio Ambiente e dos Recursos Naturais Renováveis. Auto de Infração 21. Disponível em: <http:/www.ibama.gov.br/phocadownload/ noticias_ambientais/auto_infracao_samarco_05.pdf.> Acesso em: abr. 2016.

IBAMA - Instituto Brasileiro do Meio Ambiente e dos Recursos Naturais Renováveis. Laudo Técnico Preliminar. Disponível em: < http://www.ibama.gov.br/phocadownload/ noticias_ambientais/laudo_tecnico_preliminar_Ibama. pdf.> Acesso em: abr. 2016.

IBAMA - Instituto Brasileiro do Meio Ambiente e dos Recursos Naturais Renováveis. TAC garante saneamento e recuperação de 42 mil hectares de áreas protegidas na bacia do rio Doce. Disponível em: <http://www.ibama. gov.br/publicadas/tac-garante-saneamento-e-recuperacao-de-42-mil-hectares-de-areas-protegidas-na-bacia-do-rio-doce.> Acesso em: abr. 2016.

Lecey, E. O direito penal na efetividade da tutela do meio ambiente. Revista de Direitos Difusos, 18, 2394, 2013.

Lucarelli, F. D. Responsabilidade civil por dano ecológico. Revista dos Tribunais, São Paulo: Editora Revista dos Tribunais, 700, fevereiro de 1994.

Machado, A. C. C. Código Civil interpretado. 3. ed. Barueri: Manole, 2010.

Machado, P. A. L. Direito Ambiental Brasileiro. 20. ed. São Paulo: Malheiros, 2012.

Maia, R. T. O princípio do ne bis in idem e a Constituição Brasileira de 1988. Boletim Científico da Escola Superior do Ministério Público da União, 4(16), 11-75, 2005.

Milaré, E. Direito do ambiente. 9. ed. rev., atual. e ampl. São Paulo: Editora Revista dos Tribunais, 2014.

MPOG - Ministério do Planejamento. Glossário de defesa civil estudos de riscos e medicina de desastres. 2. ed. rev. e ampl. Brasília, 2008. 
Pereira, V. S. D. A responsabilidade penal da pessoa jurídica nos crimes contra a ordem econômico-financeira. Revista Liberdades (IBCCRIM), 9, jan./abr. 2012.

STF - Supremo Tribunal Federal. Jurisprudencia. Disponível em: <www.stf.jus.br/portal/jurisprudencia>. Acesso em abr. 2016.
STJ - Superior Tribunal de Justiça. Jurisprudência. Disponível em: <http://www.stj.jus.br/SCON/>. Acesso em: abr. 2016. 